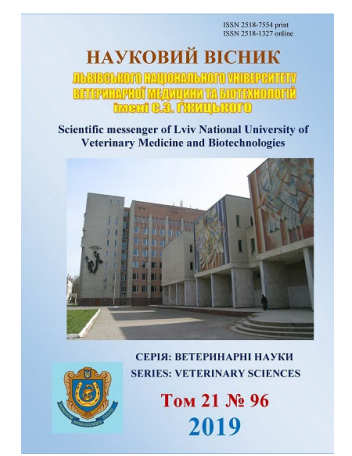

\author{
Науковий вісник Львівського національного університету \\ ветеринарної медицини та біотехнологій імені С.3. Гжицького. \\ Серія: Ветеринарні науки
}

Scientific Messenger of Lviv National University of Veterinary Medicine and Biotechnologies. Series: Veterinary sciences

UDC 619:614.48:636.084.7

\title{
Development of a regime of disinfection of milking equipment and milk inventory with the acid detergent "Milkodez"
}

\author{
M.M. Verkholiuk, R.A. Peleno, N.V. Semaniuk
}

Stepan Gzhytskyi National University of Veterinary Medicine and Biotechnologies Lviv, Ukraine

Article info

Received 25.10.2019

Received in revised form 28.11.2019

Accepted 29.11.2019

Stepan Gzhytskyi National University of Veterinary Medicine and Biotechnologies Lviv, Pekarska Str., 50, Lviv, 79010, Ukraine.

Tel.: +38-097-466-86-32

E-mail:verholuk@ukr.net
Verkholiuk, M.M., Peleno, R.A., \& Semaniuk, N.V. (2019). Development of a regime of disinfection of milking equipment and milk inventory with the acid detergent "Milkodez". Scientific Messenger of Lviv National University of Veterinary Medicine and Biotechnologies. Series: Veterinary sciences, 21(96), 153-157. doi: 10.32718/nvlvet9627

The material for the reseach were the washes that were taken from the milk utensils, portable milking machines, surface of the cooler, milking unit with the UDM 200 "Bratslavchanka" and milking parlor "Yalinka". Washing of milking equipment and milk equipment was carried out with $0.5 \%$ hot solution $\left(70 \pm 5{ }^{\circ} \mathrm{C}\right)$ of alkaline "Hyprochlor" and acid detergents disinfectant "Milkodez" and "Hypracid". Processing of milk dishes, portable milking machines and cooler with acidic means was carried out for 2 and 5 minutes, cooler for 5 and 10 minutes, and installations of milking machine with UDM 200 "Bratslavchanka" milking parlor and "Yalinka" milking parlor - for 15 minutes by pumping the solution several times using a vacuum unit. The equipment, sanitary treatment of which was carried out by means of "Hyprochlor" and "Hypracid", used as control. The disinfectant effect of the investigated agents was evaluated by the number of mesophilic aerobic and optional anaerobic microorganisms (MAOanM) in washings selected after washing and in milk. It was found that for the use of "Milkodez" dairy utensils for sanitary treatment, the amount of MAOAnM on the surface of milking buckets and glass jars was smaller compared to their treatment with "Hypracid", and the difference was for 2 and 5 min respectively 86.5\% and 57.7\% and 97.3 and $95.7 \%$, respectively. Microbial contamination of fresh milk was reduced by 50.5\% and $91.3 \%$, respectively. The smallest amount of MAOanM in washes from milking rubber, milk hose, collector and milking tank of portable milking machines was in 5 minutes of their washing "Hyprochlor" and "Milkodez" and were respectively 0.6, 0.3, 0.5 and 0.2 thousand $\mathrm{CFU} / \mathrm{sm}^{3}$, which allowed to obtain milk with the content of microorganisms 26 thousand $\mathrm{CFU} / \mathrm{sm}^{3}$. The number of microorganisms per $1 \mathrm{sm}^{3}$ of flushing from the walls of the cooler for 10 min of sanitary treatment by means of "Hyprochlor" and "Hypracid" was 5.8 thousand CFU/sm $\mathrm{sm}^{3}$, while for 5 min of exposure of the preparations "Hyprochlor" and "Milkodez" their number was 1.1 thousand $C F U / \mathrm{cm}^{3}$, and for $10 \mathrm{~min}-0.4$ thousand CFU/ $\mathrm{cm}^{3}$. Thus, the number of microbial cells in $1 \mathrm{sm}^{3}$ of milk was respectively 248000, 41000 and $29000 \mathrm{CFU}$. It is proved that for the sanitary treatment of UDM 200 "Bratslavchanka" and milking parlor "Yalinka" it is advisable to use the acid detergent disinfectant "Milkodez", which provided 11.7 and 20.3 times less total amount of microorganisms in the washes from the elements and in 3.6 and 7.1 times in fresh milk, compared to "Hypracid". The optimal mode of application of $0.5 \%$ solution of acid detergent disinfectant "Milkodez" for the effective sanitary treatment of milk utensils is 5 minutes, milking equipment - 10 minutes, and for the treatment of milking installations with milk pipeline and milking parlor - 15 minutes, after the previous washing them with an alkaline agent "Hyprochlor".

Key words: acidic agent "Milkodez", MAOanM, milking equipment, dairy equipment.

\section{Розробка режиму дезінфекції доїльного устаткування та молочного інвентарю кислотним мийно-дезінфікуючим засобом "Мілкодез"}

\author{
М.М. Верхолюк, Р.А. Пеленьо, Н.В. Семанюк
}


Львівський національний університет ветеринарної медицини та біотехнологій імені С.3. Гжицького, м. Львів, Україна

Матеріалом для дослідження були змиви, які відбирали із молочного посуду, переносних доӥльних апаратів, поверхні охолоджувача, установки доӥльної з молокопроводом УДМ 200 “Бращлавчанка” та доїльного залу “Ялинка”. Миття дойльного обладнання та молочного інвентаря проводили 0,5\% гарячим розчином $\left(70 \pm 5{ }^{\circ} \mathrm{C}\right)$ лужного засобу “Нургосhlor” $i$ кислотних мийнодезінфікуючих препаратів "Мілкодез" $i$ "Нурracid". Обробку молочного посуду, переносних доӥльних апаратів $і$ охолоджувача кислотними засобами проводили 2 та 5 хв, охолоджувача - 5 та 10 хв, а установки доӥльної з молокопроводом УДМ 200 “Браилавчанка" $і$ доїльного залу “Ялинка" - упродовж 15 хвилин шляхом декілька разового прокачування робочих розчині за допомогою вакуумної установки. Обладнання та інвентар, санітарну обробку яких проводили засобами “Нургосhlor” $i$ “Нургасіd”, слугувало контролем. Дезінфекиійну дію досліджуваних засобів оцінювали за кількістю мезофільних аеробних $і$ факультативно анаеробних мікроорганізмів (МАФАнМ) у змивах, відібраних після миття, і у молоці. Встановлено, щзо за використання для санітарної обробки молочного посуду засобу “Мілкодез” кількість МАФАнМ на поверхні відер для дойння та скляних банок була меншою, порівняно із їх обробкою засобом “Нурracid”, і різниця, за 2 та 5 хв експозиції становила відповідно 86,5 і 57,7\% та 97,3 і 95,7\%. При цььому, мікробне забруднення свіжонадоєного молока було меншим на 50,5 та 91,3\%. Найменша кількість МАФАнМ у змивах із доӥльної гуми, молочного шлангу, колектора і дойльного бачка переносних доӥльних апаратів була за 5 хв їх миття “Нургосһlог” та “Мілкодез” і становила відповідно 0,6, 0,3, 0,5 та 0,2 тис. КУО/см, щуо дозволило одержати молоко із вмістом мікроорганізмів 26 тис. КУО/см ${ }^{3}$. Кількість мікроорганізмів у $1 \mathrm{~cm}^{3}$ змиву із стінок охолоджувача за 10 хв санітарної обробки засобами “Нургосһlог” $i$ “Нурracid” становила 5,8 тис. КУО/см в в той час, як за 5 хв експозиції препаратів “Нургосhlor” $i$ “Мілкодез” їх кількість була

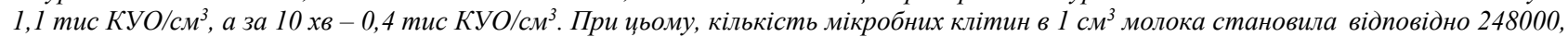
41000 і 29000 КУО. Доведено, щзо для санітарної обробки УДМ 200 “Бращлавчанка” і доӥльного залу “Ялинка” доцільно використовувати кислотний мийно-дезінфікуючий засіб “Мілкодез”, який забезпечував в 11,7 та 20,3 раза меншу сумарну кількість мікроорганізмів у змивах із елементів і в 3,6 та 7,1 раза у свіжонадоєному молочі, порівняно із засобом “Нургасід”. Визначено, щзо оптимальним режимом застосування 0,5\% розчину кислотного мийно-дезінфікуючого засобу “Мілкодез” для ефективної санітарної обробки молочного посуду є 5 хв, доӥльного обладнання - 10 хв, а установок дойльних з молокопроводом та доӥльних залів - 15 хв, після попереднього їх миття лужним засобом “Нургосhlor”.

Ключові слова: кислотний засіб “Мілкодез”, МАФАнМ, доӥльне обладнання, молочний інвентар.

Вступ

Згідно з нормативними документами Європейського Союзу та Державним стандартом України (ДСТУ 3662:2018) молоко, яке доставляють на молочні заводи, за показниками якості повинно відповідати вимогам екстра-гатунку і кількість МАФАнМ у ньому має бути меншою 100000 мікробних клітин у 1 cм$^{3}$ (DSTU 3662:2018, 2018). Отримати молоко такої якості у господарстві є можливим лише тоді, коли кількість МАФАнМ у свіжонадоєному молоці не перевищує 30 тис. мікробних клітин у $1 \mathrm{~cm}^{3}$, охолодження після доїння до температури +4 С відбувається не довше 3 год., молоко у господарстві зберігається до 24 год. і транспортується на переробку у холодильниках (Elmoslemany et al., 2010; Kukhtyn et al., 2015; Velázquez-Ordoñez et al., 2019).

Касянчук В.В. (2006), Vilar M.J. (2016) вказують, що мікробне число молока до 30 тис. мікробних клітин в 1 см $^{3}$ можна забезпечити лише тоді, коли кількість мікробів у змивах із доїльного обладнання та молочного інвентаря не буде перевищує 500 клітин в $1 \mathrm{~cm}^{3}$ (Kasyanchuk et al., 2006; Vilar et al., 2012).

Таких показників важко досягти в малих фермерських та особистих селянських господарствах, у яких доїння корів проводять вручну, або за допомогою переносних доїльних апаратів, а санітарну обробку обладнання та інвентаря - водою, за допомогою щіток (Perin et al., 2012; Layter-Moskalyuk et al., 2016; Kovalenko et al., 2018).

Саме тому, актуальним залишається питання розробки нових, ефективних засобів для миття і дезінфекції доїльного обладнання та молочного інвентаря та режимів їх використання.
Мета і завдання дослідження. Метою роботи було розробити науково обгрунтовані режими проведення санітарної обробки молочного інвентарю і доїльного обладнання новим кислотним мийно-дезінфікуючим засобом “Мілкодез”. Для досягнення поставленої мети були поставлені такі завдання:

- порівняти кількість МАФАнМ у змивах із молочного посуду, переносних доїльних апаратів і поверхні охолоджувача після їх миття лужним засобом "Hyprochlor" у поєднанні із кислотними "Hypracid" та "Мілкодез";

- дослідити мікробне забруднення свіжонадоєного та збірного охолодженого молока, одержаного 3 використанням обладнання, для дезінфекції якого використовували кислотні препарати "Нурracid" та "Мілкодез";

- визначити ефективність кислотних мийнодезінфікуючих засобів "Нурracid" і “Мілкодез" для санітарної обробки установки доїльної з молокопроводом УДМ 200 “Брацлавчанка” та доїльного залу "Ялинка";

- запропонувати ефективні, науковообгрунтовані режими дезінфекції доїльного устаткування та молочного інвентарю кислотний мийнодезінфікуючим засобом “Мілкодез”.

\section{Матеріал і методи досліджень}

Матеріалом для дослідження були змиви, відібрані iз доїльного обладнання та молочного інвентаря i молоко. Санітарну обробку доїльного посуду та переносних доїльних апаратів здійснювали $0,5 \%$ гарячим розчином $\left(70 \pm 5^{\circ} \mathrm{C}\right)$ лужного засобу “Hyprochlor", а дезінфекцію - впродовж 2 і 5 хв робочими розчинами 
кислотних мийно-дезінфікуючих засобів “Мілкодез” і "Hypracid".

Миття та дезінфекцію охолоджувача робочими розчинами засобів "Hyprochlor" та "Нурracid" проводили 10 хвилин за стандартною схемою. Розроблений нами кислотний мийно-дезінфікуючий засіб "Мілкодез” застосовували упродовж 5 та 10 хвилин, після попереднього миття охолоджувача "Нyprochlor".

Для санітарної обробки установки доїльної з молокопроводом УДМ 200 "Брацлавчанка" та доїльного залу “Ялинка" використовували поєднання засобів "Hyprochlor" із "Hурracid" та "Нурrochlor" із "Мілкодез” робочі розчини яких, упродовж 15 хвилин, декілька разів прокачували через них за допомогою вакуумної установки.

Кількість МАФАнМ у змивах і молоці визначали загальноприйнятим методом (Yakubchak et al., 2005; Perkiy et al., 2012).

Одержані результати піддавали ст атистичній обробці, яку проводили методом варіаційної статистики 3 визначенням середніх значень величин і середньої похибки. Вірогідність відмінностей між середніми значеннями під час проведення аналізу оцінювали, використовуючи критерії Стьюдента (t). Відмінність між величинами вважали вірогідною, коли ймовірність різниці становила $\mathrm{P} \leq 0,05$.

\section{Результати та їх обговорення}

Результати мікробіологічного дослідження змивів iз молочного посуду, переносних доїльних апаратів i поверхні охолоджувача після санітарної обробки та свіжонадоєного i збірного охолодженого молока, одержаного за використанням вказаного обладнання, представлено на рис. 1-4.

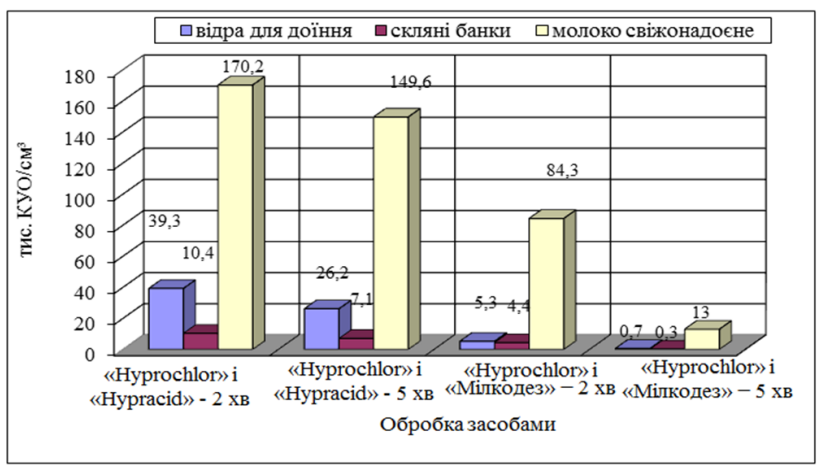

Рис. 1. Кількість МАФАнМ у змивах із молочного посуду після санітарної обробки та свіжонадоєному

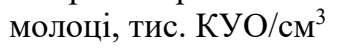

Як видно із даних рис. 1, кількість МАФАнМ у змивах із відер та скляних банок після їх миття гіпрохлором та 2 хв обробки гіпрацидом та мілкодезом була відповідно $39,3 \pm 2,94$ і 10,4 \pm 0,74 та 5,3 $\pm 0,35$ i 4,4 $\pm 0,36$ тис. КУО/см ${ }^{3}$ При цьому, кількість МАФАнМ у свіжонадоєному молоці, одержаному за допомогою вказаного молочного посуду, становила відповідно $170,2 \pm 13,79$ та $84,3 \pm 6,15$ тис. КУО/см³. Збільшення тривалості обробки до 5 хв зумовило зменшен- ня кількості МАФАнМ у змивах відповідно на 33,3 і 31,7 та 86,8 і $93,2 \%$ та на 12,1 і $84,6 \%$ у свіжонадоєному молоці.

За використання засобу “Мілкодез" кількість МАФАнМ на поверхнях відер для доїння та скляних банок була меншою, порівняно із їх обробкою "Нypracid", і різниця, за 2 хв експозиції становила 86,5 та 57,7\%, а за експозиції 5 хв - відповідно 97,3, 95,7\%. Мікробне забруднення свіжонадоєного молока, одержаного за допомогою посуду, який обробляли мідкодезом впродовж 2 і 5 хв було меншим на 50,5 та $91,3 \%$, порівняно із молоком надоєним у посуд митий гіпрацидом.

Результати визначення кількості МАФАнМ у змивах із переносних доїльних апаратів після санітарної обробки досліджуваними мийно-дезінфікуючими засобами, наведено на рис. 2.

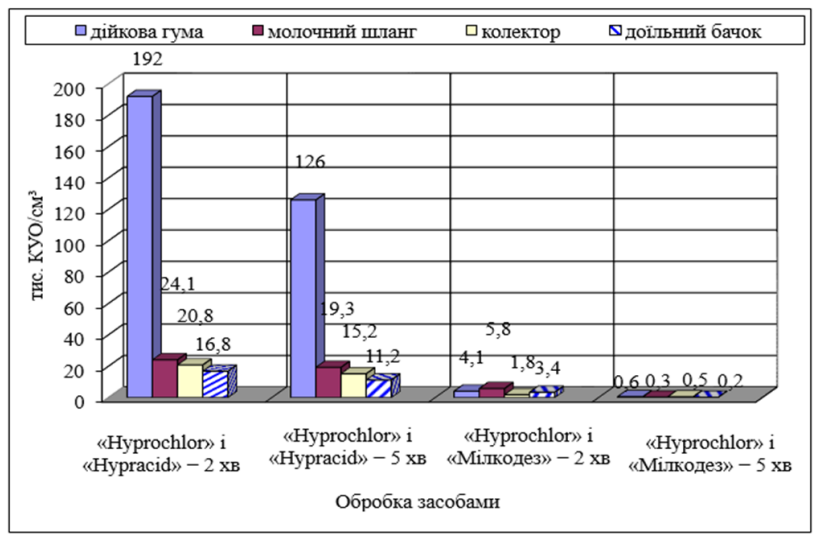

Рис. 2. Кількість МАФАнМ у змивах із переносних доїльних апаратів після санітарної обробки, тис. $\mathrm{KУO} / \mathrm{cm}^{3}$

Встановлено, що використання кислотного засобу "Нурracid” для санітарної обробки переносних доїльних апаратів упродовж 2 хв після їх миття хлорвмісним засобом "Нурrochlor" не забезпечило належної чистоти обладнання. Так, кількість мікроорганізмів у звивах із дійкової гуми становила $192 \pm 1,56$ тис. $\mathrm{KУО} / \mathrm{cm}^{3}$, молочного шлангу - $24,1 \pm 1,85$, колектора $20,8 \pm 1,51$ і доїльного бачка - 16,8 $\pm 1,21$ тис.

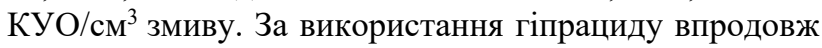
5 хв кількість тис. КУО/ $\mathrm{cm}^{3}$ змиву була меншою відповідно на 34,4, 19,9, 26,9 і 33,4\%.

Обробка досліджуваного обладнання лужним засобом "Нурrochlor" i кислотним мийнодезінфікуючим "Мілкодез” була ефективнішою, порівняно із обробкою "Нyprochlor" i "Нypracid". Найменша кількість МАФАнМ була у змивах зроблених за 5 хв експозиції мілкодезу. Порівняно із експозицією 2 хв, їх кількість на доїльній гумі була меншою на $85,4 \%$, у молочному шлангу - на 94,8, у колекторі - на 72,2 і у доїльному бачку - на 94,1\%.

Кількість МАФАнМ у свіжонадоєному молоці одержаному 3 використанням переносних доїльних апаратів помитих засобами "Hyprochlor", "Hypracid" i “Мілкодез” представлено на рис. 3. 


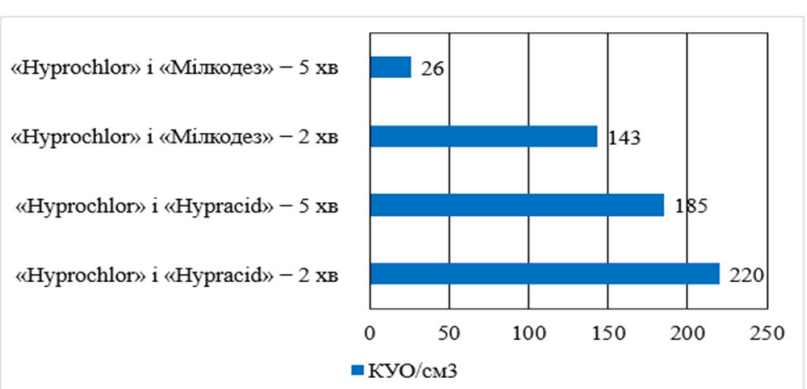

Рис. 3. Кількість МАФАнМ у молоці надоєному переносними доїльними апаратами, помитими засобами "Hyprochlor”, "Нурracid” і “Мілкодез”, тис. КУО/см ${ }^{3}$

У молоці надоєному переносними доїльними апаратами, для санітарної обробки яких впродовж 2 хв використовували "Нyprochlor" i "Нypracid", кількість

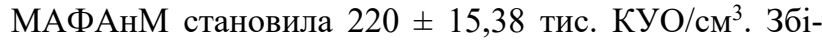
льшення часу миття до $5 \mathrm{xв}$, зумовило зменшення кількість МАФАнМ у молоці на $15,9 \%$.

За санітарної обробки доїльних апаратів засобами "Hyprochlor" і “Мілкодез" впродовж 2 хв кількість МАФАнМ у молоці становила $143 \pm 10,57$ тис. КУО/ $\mathrm{cm}^{3}$, а 5 хв експозиція забезпечила умови, необхідні для одержання молока екстра гатунку, так як кількість мікроорганізмів становила $26 \pm 2,11$ тис. $\mathrm{KУО} / \mathrm{cm}^{3}$ молока.

Результати, представлені на рис. 4, свідчать про те, що за обробки охолоджувача упродовж 10 хв засобами "Hyprochlor" i "Нурracid" кількість мікроорганізмів у $1 \mathrm{~cm}^{3}$ змиву із стінок становила $5,8 \pm 0,48$ тис. $\mathrm{KУО} / \mathrm{cm}^{3}$, а у збірному молоці $-248 \pm 19,35$ тис КУО/ $\mathrm{cm}^{3}$.

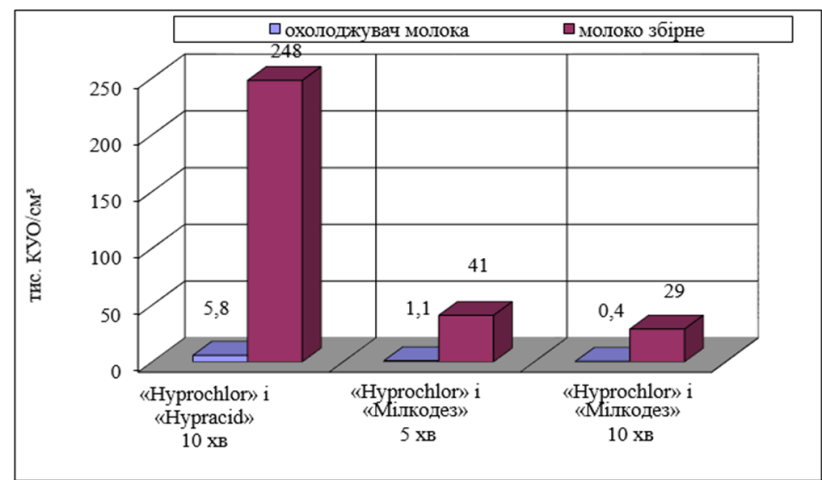

Рис. 4. Кількість МАФАнМ у змивах із поверхні охолоджувача після санітарної обробки і збірному молоці, тис. КУО/ $\mathrm{cm}^{3}$

За застосування мілкодезу упродовж 5 і 10 хв кількість МАФАнМ на поверхні охолоджувача біла меншою у 5,2 і 14,5 раза, а у збірному молоці - відповідно у 6 та 8,6 раза, порівняно із застосуванням гіпрациду.

Досліджуючи ефективність кислотних мийнодезінфікуючих засобів "Нурracid" і “Мілкодез” для санітарної обробки установки доїльної з молокопроводом УДМ 200 “Брацлавчанка" встановлено, що за 15 хв їі миття робочим розчином гіпрациду кількість МАФАнМ в $1 \mathrm{~cm}^{3}$ змиву 3 дійкової гуми становила

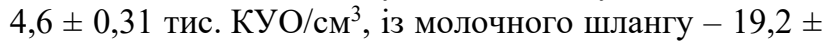

1,43 , із колектора $-8,2 \pm 0,62$, у воді з молокопроводу $-9,5 \pm 0,77$ і у молоці $-111,2 \pm 8,45$ тис. КУО/ $\mathrm{cm}^{3}$.

За обробки УДМ 200 "Брацлавчанка" препаратом "Мілкодез" сумарна кількість мікроорганізмів у змивах із їі елементів була меншою в 11,7 раза, а в свіжонадоєному молоці - у 3,6 раза, порівняно із застосуванням засобів "Нурrochlor" i "Нурracid". Так, кількість МАФАнМ в $1 \mathrm{~cm}^{3}$ змиву 3 дійкової гуми була меншою на 93,4\%, із молочного шлангу - на 96,9, із колектора - на 91,5, у воді з молокопроводу - на 95,8 i у молоці - на $72,1 \%$

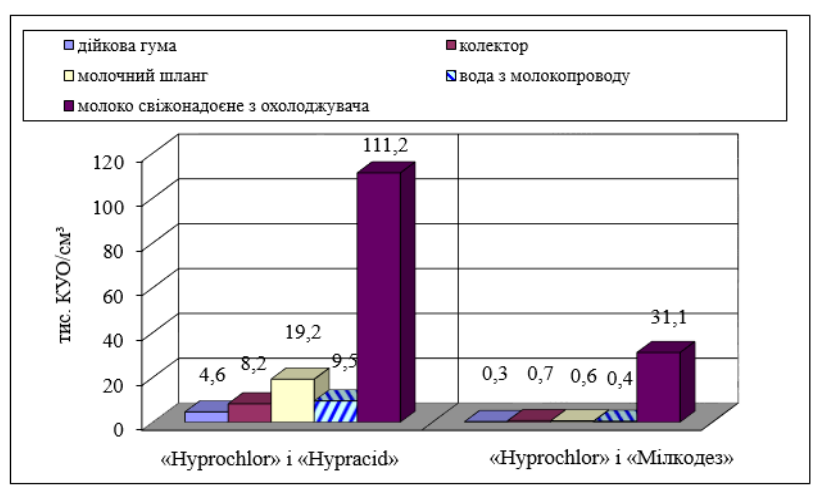

Рис. 5. Кількість МАФАнМ у змивах із елементів УДМ 200 “Брацлавчанка" та води з молокопроводу після санітарної обробки, тис. КУО/ $\mathrm{cm}^{3}$

Ефективнішим, порівняно із засобом "Нурracid", мілкодез був і при його застосуванні для санітарної обробки доїльного залу “Ялинка”.

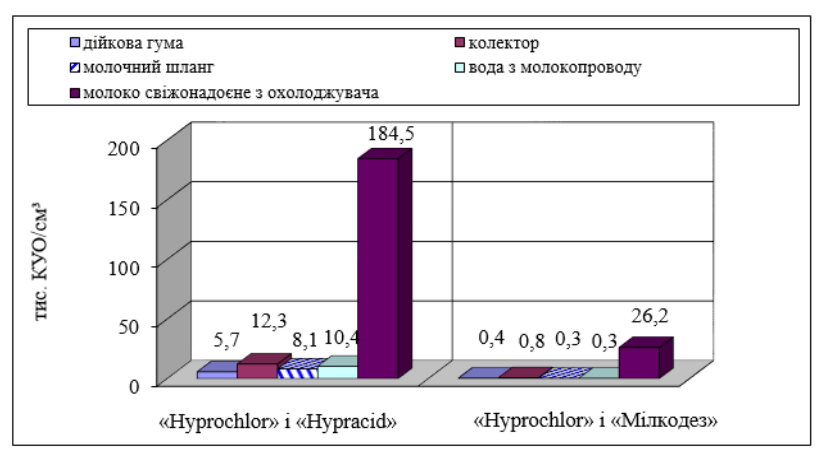

Рис. 6. Кількість МАФАнМ у змивах із елементів доїльного залу “Ялинка” та води з молокопроводу після санітарної обробки, тис. КУО/ $\mathrm{cm}^{3}$

Із результатів, наведених на рис. 6 видно, що за експозиції 15 хв, після миття обладнання 0,5\% розчином лужного засобу«Нурrochlor» кількість МАФАнМ в $1 \mathrm{~cm}^{3}$ змиву із дійкової гуми, молочного шлангу, колектора, води з молокопроводу і у молоці становила $0,4 \pm 0,03,0,3 \pm 0,02,0,8 \pm 0,06,0,3 \pm 0,02$ i $26,2 \pm 2,07$ тис. КУО/см ${ }^{3}$, що відповідно у 14,3, 15,4, 27, 34,7 і 7 разів менше, порівняно із показниками, одержаними за використання засобу "Нypracid". 


\section{Висновки}

1. За використання засобу “Мілкодез” для санітарної обробки молочного посуду кількість МАФАнМ на поверхнях відер для доїння та скляних банок була меншою, порівняно із їх обробкою засобом "Hypracid", i різниця, за 2 та 5 хв експозиції становила відповідно 86,5 і $57,7 \%$ та 97,3 і 95,7\%, а мікробне забруднення свіжонадоєного молока було меншим на 50,5 та 91,3\%. Найменша кількість МАФАнМ у змивах із доїльної гуми, молочного шлангу, колектора i доїльного бачка переносних доїльних апаратів була за 5 хв їх миття "Нyprochlor" та "Мілкодез" і становила відповідно $0,6 \pm 0,04,0,3 \pm 0,02,0,5 \pm 0,04$ та $0,2 \pm$ 0,01 тис. КУО/ $\mathrm{cm}^{3}$, що дозволило одержати молоко із вмістом мікроорганізмів $26 \pm 2,12$ тис. КУО/ $\mathrm{cm}^{3}$.

2. Кількість мікроорганізмів у $1 \mathrm{~cm}^{3}$ змиву із стінок охолоджувача за 10 хв санітарної обробки засобами "Hyprochlor" i "Нурracid" становила 5,8 0,48 тис. КУО $/ \mathrm{cm}^{3}$ в той час, як за 5 хв експозиції препаратів "Нурrochlor" i “Мілкодез" їх кількість була $1,1 \pm 0,08$ тис $\mathrm{KУО} / \mathrm{cm}^{3}$, а за 10 хв $-0,4 \pm 0,03$ тис КУО/см ${ }^{3}$. При цьому, кількість мікробних клітин в $1 \mathrm{~cm}^{3}$ молока становила відповідно $248000 \pm 19344$, $41000 \pm 3362$ і $29000 \pm 2291$ КУО.

3. Для санітарної обробки УДМ 200 "Брацлавчанка" і доїльного залу “Ялинка" доцільно використовувати робочий розчин кислотного мийнодезінфікуючого засобу “Мілкодез”, який забезпечував в 11,7 та 20,3 раза меншу сумарну кількість мікроорганізмів у змивах із елементів і в 3,6 та 7,1 раза у свіжонадоєному молоці, порівняно із засобом "Hypracid".

4. Оптимальним режимом застосування 0,5\% розчину кислотного мийно-дезінфікуючого засобу “Мілкодез” для ефективного проведення санітарної обробки молочного посуду є 5 хв, доїльного обладнання - 10 хв, а для обробки установок доїльних 3 молокопроводом та доїльних залів - 15 хв, після попереднього їх миття лужним засобом "Hyprochlor".

\section{References}

DSTU 3662:2018 (2018). Moloko-syrovyna korovyache. Tekhnichni umovy. [Chynnyy vid 2019-01-01]. Kyyiv: Derzhspozhyvstandart Ukrayiny (in Ukrainian).

Elmoslemany, A.M., Keefe, G.P., Dohoo, I.R., Wichtel, J.J., Stryhn, H., \& Dingwell, R.T. (2010). The association between bulk tank milk analysis for raw milk quality and on-farm management practices. Preventive Veterinary Medicine, 95(1-2), 32-40. doi: 10.1016/j.prevetmed.2010.03.007.

Kasyanchuk, V., Kryzhanivs'kyy, YA.Y., \& Danylenko, I.A. (2006). Retel'nyy kontrol' vyrobnytstva moloka na fermi - osnovnyy vazhil' u zabezpechenni naselennya vysokoyakisnoyu produktsiyeyu. Tvarynnytstvo Ukrayiny, 4, 20-22 (in Ukrainian).
Kovalenko, V.L., Kovalenko, P.L., Ponomarenko, G.V., Kukhtyn, M.D., Midyk, S.V., Horiuk, Y.V., \& Garkavenko, V.M. (2018). Changes in lipid composition of Escherichia coli and Staphylococcus areus cells under the influence of disinfectants Barez ${ }^{\circledR}$, Biochlor ${ }^{\circledR}$ and Geocide $\AA$. Ukrainian Journal of Ecology, 8(1), 547-550. doi: 10.15421/2018_248.

Kukhtyn, M.D., Perkiy, YU.B., \& Pokotylo, O.S. (2015). Efektyvna sanitarna obrobka tekhnolohichnoho obladnannya yak osnova bezpechnoho vyrobnytstva. Molochna industriya, 4, 26-27 (in Ukrainian).

Layter-Moskalyuk, S.V., Reshetnyk, A.O., Horyuk, V.V., \& Perkyy, YU.B. (2016). Razrabotka rezhymov sanytarnoy obrabotky doylnoho oborudovanyya kyslotnym sredstvom "TDS". Naukovyy visnyk Lvivskoho natsionalnoho universytetu veterynarnoyi medytsyny ta biotekhnolohiy imeni S.Z. Gzhytskoho, 18, 1(65), 188-192. https://cyberleninka.ru/article/n/ razrabotka-rezhimov-sanitarnoy-obrabotki-doilnogooborudovaniya-kislotnym-sredstvom-tds/viewer (in Ukrainian).

Perin, L.M., Moraes, P.M., \& Nero, L.A. (2012). Interference of storage temperatures in the development of mesophilic, psychrotrophic, lipolytic and proteolytic microbiota of milk. Semina: Ciências Agrárias, 33(1), 333-342. doi: 10.5433/1679-0359.2012v33n1p333.

Perkiy, YU.B., Kryzhanivskyy, YA.Y, Kryvokhyzha, YE.M., Motkalyuk, N.F., Kukhtyn, M.D., \& Krushelnytska, N.V. (2012). Otsinka prydatnosti ta efektyvnosti myynykh, dezinfikuyuchykh i myynodezinfikuyuchykh zasobiv dlya sanitarnoyi obrobky doyil'noho ustatkuvannya ta molochnoho inventarya (Metodychni rekomendatsiyi). Zatverdzhenni naukovo-tekhnichnoyu radoyu Derzhavnoyi veterynarnoyi ta fitosanitarnoyi sluzhby Ukrayiny, protokol №1 vid 21 hrudnya 2012 roku (in Ukrainian).

Velázquez-Ordoñez, V., Valladares-Carranza, B., Tenorio-Borroto, E., Talavera-Rojas, M., Varela-Guerrero, J.A., Acosta-Dibarrat, J., Puigvert, F., Grille, L., González Revello, Á. \& Pareja, L. (2019). Microbial Contamination in Milk Quality and Health Risk of the Consumers of Raw Milk and Dairy Products, Nutrition in Health and Disease - Our Challenges Now and Forthcoming Time, Gyula Mózsik and Mária Figler, IntechOpen. doi: 10.5772/intechopen.86182.

Vilar, M.J., Rodríguez-Otero, J.L., Sanjuán, M.L., Diéguez, F.J., Varela, M., \& Yus, E. (2012). Implementation of HACCP to control the influence of milking equipment and cooling tank on the milk quality. Trends in Food Science \& Technology, 23(1), 4-12. doi: 10.1016/j.tifs.2011. 08.002.

Yakubchak, O.M., Kovalenko, V.L., Khomenko, V.I., Denysyuk, H.M., Bondar, T.O., \& Midyk, S.V. (2005). Rekomendatsiyi shchodo sanitarnomikrobiolohichnoho doslidzhennya zmyviv $\mathrm{z}$ poverkhon test-obyektiv ta obyektiv veterynarnoho nahlyadu i kontrolyu: Metodychni rekomendatsiyi. Kyyiv: NAU (in Ukrainian). 